\title{
The Fatigue Crack Growth Rate Due to Single-Step Austempered Heat Treatment in Nodular Cast Iron
}

\author{
Andoko Andoko ${ }^{1, *}$, and Poppy Puspitasari ${ }^{1}$ \\ ${ }^{1}$ Mechanical Engineering Department, Engineering Faculty, Universitas Negeri Malang, Indonesia
}

\begin{abstract}
Nodular cast iron comes to be the most used material in manufacturing industry. Recently, a number of engineering to enhance the mechanical properties of nodular cast iron have been being given including through the heat treatment called single-step austempered. In general, the process of single-step heat treatment is conducted through austenization at the temperature of $900^{\circ} \mathrm{C}$ with the holding time of 60 minutes and quenched at various austempered temperatures of 280,310 , and $340^{\circ} \mathrm{C}$ in the holding time of 60 and 120 minutes. The observation on fatigue crack behaviour was performed in comparison of stress $\mathrm{R}=0$ and at $11-\mathrm{Hz}$ frequency. From the result of the research, a graphic about relationship of crack length (a) and the number of cycles $(\mathrm{N})$, and the graphic of the fatigue crack growth rate $(\mathrm{da} / \mathrm{dN})$ with the stress intensity factor of $(\Delta \mathrm{k})$. In addition, it is found that the single-step austempered heat treatment at the austempered temperature at $340^{\circ} \mathrm{C}$ with the holding time of 120 minutes showed a slower fatigue crack growth rate in comparison to the temperature and time below. The slowness of the fatigue crack growth rate was caused by the higher percentage of the pearlite matrix phase in comparison to the ferrite matrix, nodular distance, and the relatively even nodule distribution.
\end{abstract}

\section{Introduction}

One of the weaknesses of cast iron is related to its brittleness, thus being liable to break easily particularly in accepting a dynamic loading, impact loading (sudden attack) or flexure loading. In response to these weaknesses, British Cast Iron Research Association (BCIRA) in 1948 mixed some elements such as cerium, copper, nickel and other alloyed elements into the cast iron in order to result in a round-shaped graphite cast iron. This endeavour was then followed by the emergence of some tests, one of which is by adding the magnesium into cast iron. Based on the result of metallographic test, it is known that the addition of magnesium into the cast iron is able to produce the round-shaped graphite cast iron and the result from the laboratory test reveals that nodular graphite in fact has tensile strength and other mechanical properties that can reach double - even its ductility is comparable to carbon steel. This finding was then patented in 1949, later remarked as the year of the emergence of Nodular

\footnotetext{
*Corresponding author: andoko.ft@um.ac.id
} 
Cast Iron (also called as Ferro Casting Ductile or FCD) [1]. Further, to improve the mechanical and other physical properties of nodular cast iron (FCD), the heat treatment was given in which the result of this treatment process is known as Austempered Ductile Iron (ADI).

The heat treatment on FCD is performed through the heating process at the proper temperature with a number of holding times. Subsequently, FCD is processed for cooling at a lower temperature with certain speed. In other words, temperature and time are becoming two core parts in heat treatment. The heat treatment on FCD is aimed to improve its mechanical properties either in strength, hardness, ductility and toughness [2]. Also, it is to reduce the residual stress and wear resistance of cast materials given the heat treatment [3]. It has been recognized so long that Austempered Ductile Iron (ADI) has the high level of ductility, strength, wear resistance, toughness and machinability that can substitute the wrought steel in various applications [4]. ADI has been proven as a suitable material for the high abrasive wear resistance - even better than that of wrought steel. For these natures, ADI is able to substitute the wrought steel in any applications [5], some of which are used in Crankshaft, camshaft, and other agricultural devices.

\section{Methodology}

The specimens consist of three types of treatment which are single step austempered at $280^{\circ} \mathrm{C}, 310^{\circ} \mathrm{C}$, and $340^{\circ} \mathrm{C}$ with holding time at 60 minutes and 120 minutes. The observation and analysis on the tested specimens have been conducted by observing the crack length (a) and the number of cycles $(\mathrm{N})$ in the testing machine of fatigue. The results of the observation on the crack length and the number of cycles were recorded to be used in making a plot of correlation diagram between the crack length (a) and cycle number $(\mathrm{N})$ and to measure the fatigue crack growth rate $(\mathrm{da} / \mathrm{dN})$ and the stress intensity factor $(\Delta \mathrm{k})$. The test to observe the crack length and the number of cycles was performed at the stress ratio $(\mathrm{R}=0)$ with the stress level $1 / 3$ yield strength at the frequency of $11 \mathrm{~Hz}$.

\section{Results and discussion}

\subsection{Fatigue crack growth test}

Fatigue crack growth of specimens were observed using cyle $(\mathrm{N})$ versus crack length graph and $\mathrm{dA} / \mathrm{dN}$ versus $\Delta \mathrm{k}$. There were two set of fatigue crack growth graphs for two different holding times with three different heating temperatures $\left(280^{\circ} \mathrm{C}, 310^{\circ} \mathrm{C}\right.$, and $\left.340^{\circ} \mathrm{C}\right)$. 


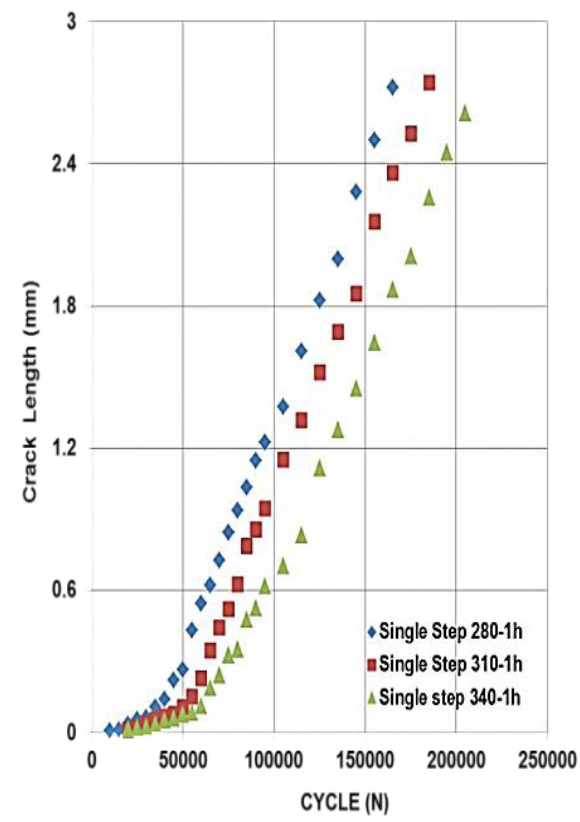

(a)

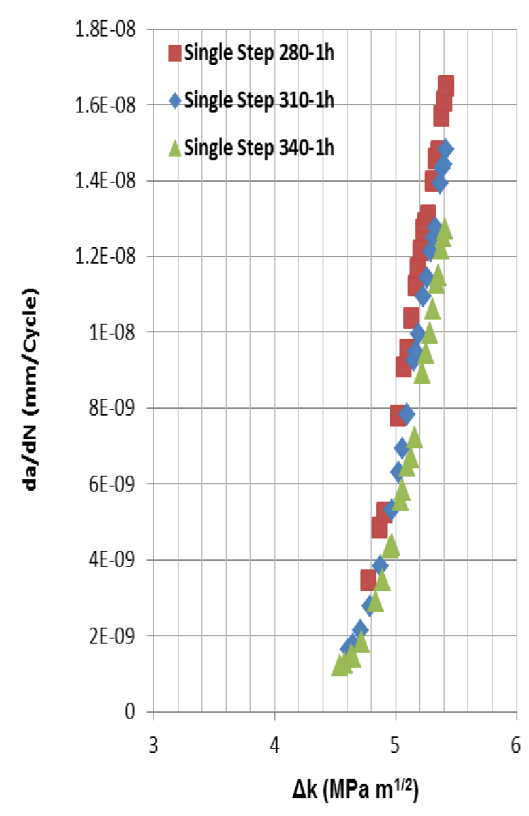

(b)

Fig. 1. The Graphic of Correlation between the crack length (a) and the number of cycles (N) b. The graphic of correlation between $(\mathrm{da} / \mathrm{dN})$ and $(\Delta \mathrm{k})$

Figure 1a shows the graphic of correlation between the crack length (a) and the number of cycles $(\mathrm{N})$ in the single step with various austempered temperatures $\left(280,310\right.$ and $\left.340^{\circ} \mathrm{C}\right)$ for the holding times of 60 minutes. Meanwhile, Figure $1 \mathrm{~b}$ presents the graphic of correlation between the fatigue crack growth rate $(\mathrm{da} / \mathrm{dN})$ and the stress intensity factor $(\Delta \mathrm{k})$ in single step with various austempered temperatures $\left(280,310\right.$ and $\left.340^{\circ} \mathrm{C}\right)$ for the holding times of 60 minutes. 


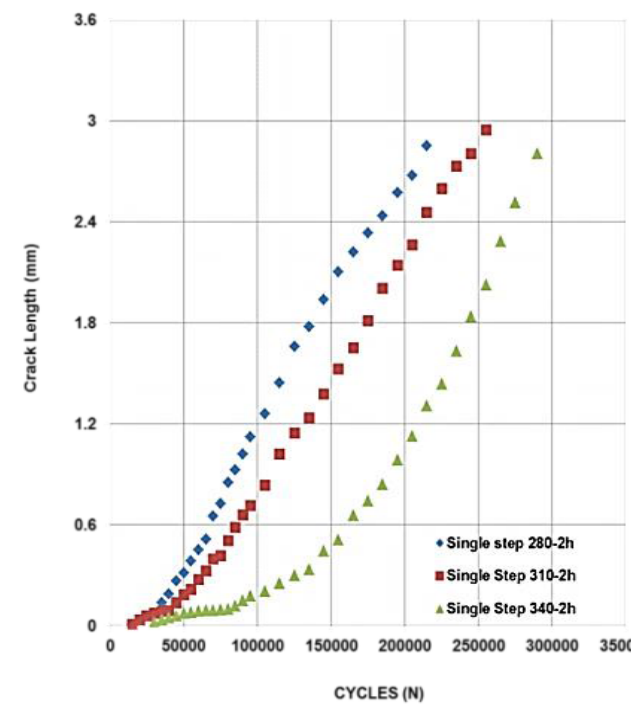

(a)

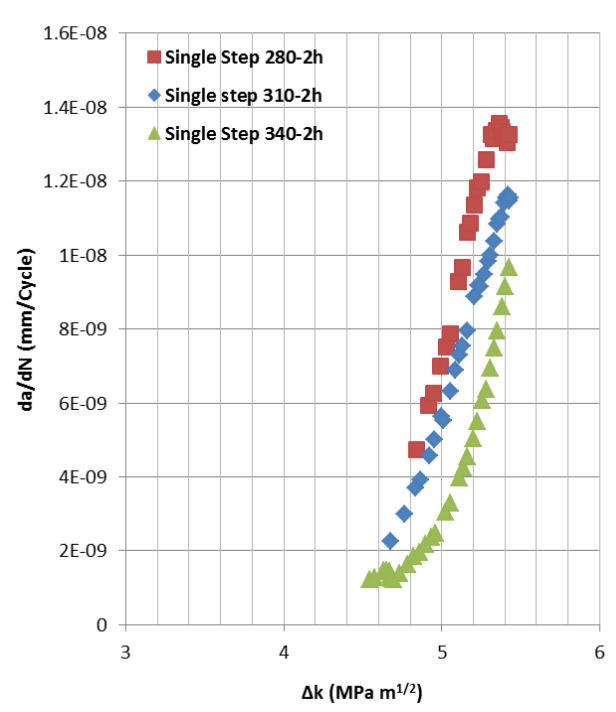

(b)

Fig. 2. The graphic of correlation between the crack length (a) and the number of cycles (N). (b) The graphic of correlation between $(\mathrm{da} / \mathrm{dN})$ and $(\Delta \mathrm{k})$

Figure $2 \mathrm{a}$ shows a combination of the graphics of the correlation between the crack length (a) and the number of cycles (n) in single step with various austempered temperatures (280, 310 and $340^{\circ} \mathrm{C}$ ) for the holding times of 60 minutes and 120 minutes on each temperature. Figure $2 b$, meanwhile, shows the combination of the graphic of the correlation between the fatigue crack growth rate $(\mathrm{da} / \mathrm{dN})$ and the stress intensity factor $(\Delta \mathrm{k})$ in single step with various austempered temperatures $\left(280,310\right.$ and $\left.340^{\circ} \mathrm{C}\right)$ for the holding times of 60 minutes and 120 minutes.

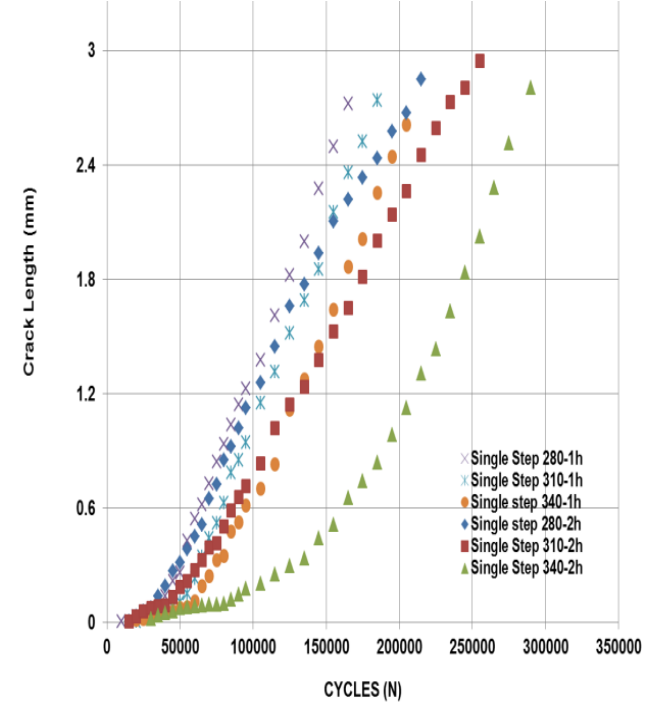

(a)

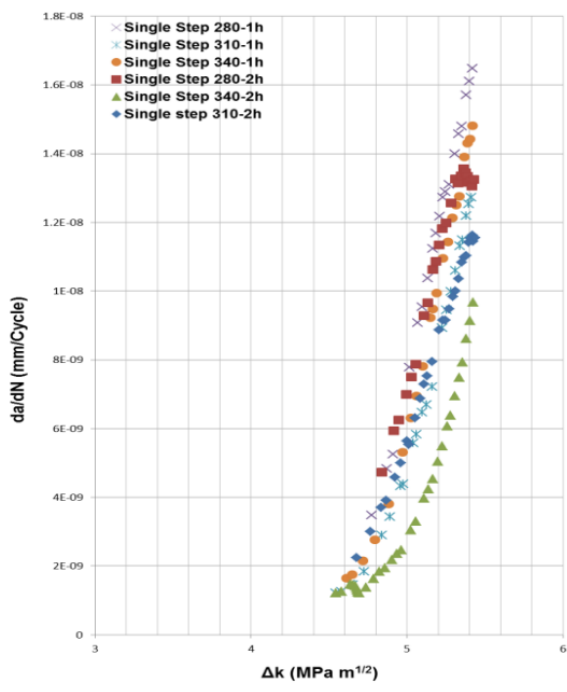

(b)

Fig. 3. The graphic of correlation between the crack length (a) and the number of cycles (N). (b) the graphic of correlation between $(\mathrm{da} / \mathrm{dN})$ and $(\Delta \mathrm{k})$ 
As seen in that graphic combination (Figure 3), the best results for the crack length and the number of cycles were obtained at the austempered temperature at $340^{\circ} \mathrm{C}$ with the holding time of 120 minutes in comparison to other temperatures and holding times. It shows that the failure in material occurred approximately in $28,000,46,300$ and 70,200 cycles for $R=0.1$. In contrast, there was no any failure when the specimen was tested at the maximum voltage of $500 \mathrm{MPa}$ with the ratio of $\mathrm{R}=0.1$. For the ratio of $\mathrm{R}=0,5$ with the application of maximum tension of $1100 \mathrm{MPa}$, the failure occurred around 32,000-43,000. The initiation of the fatigue crack exclusively occurred in pores present both on the surface and directly under the surface. Decohesion of the nodular graphite and the next initiation and the micro crack growth can cause the deflection of the dominant crack system. This also indicates a significant increase in the frequency of the nodular graphite along the crack paths as the tension increased and the further initiation (limited to the nodular graphite on crack tip the plastic zone) for the crack occurred to spread the crack tip that was dominant during the specimen period. Thus, the change in the cast micro caused by the heat treatment has caused the more fatigue level in the performance of the crack growth. This was in view of the lack of eutectic carbide and the relatively high number of austenite in micro.

The austempered temperature at $340^{\circ} \mathrm{C}$ with the holding time of 120 minutes at single step showed a microstructure in the form of the refined ausferrite with the remaining austenite phase added by the number, size and the evener graphite distribution. The content of the remaining austenite is fewer than that of the ferrite acicular phase. The longer the austempered time was, the more the ausferrite were formed. However, in the austempered time of 120 minutes with the austempered temperature at $340^{\circ} \mathrm{C}$ in single step the content of the ausferrite got fewer, then making the mechanical properties particularly the tensile strength and toughness resulted lower compared to the two step austempered. [6]

The specimen of the result of single step heat treatment showed a matrix formed by the coarse laths from acicular ferrite, the characteristics of upper part of bainite, and pieces of austenite with a number of remainders of ferrite around graphite elements. The characters of matrix and distribution of nodular graphite in general had a significant influence on fatigue. A previous research has shown that the fatigue strength of the result of heat treatment increased with the increase of the number of nodules, distribution, uniformity and the shape of nodule [7]. In addition, the fatigue strength was influenced by the nodular orientation and the distance between the relative nodular graphite towards the load direction. The pores and microshrinkages were also observed in the tested material in which they had a significant influence at the beginning of fatigue crack growth as shown in [8].

In single step, the crack path started growing due to the presence of stress concentration on the notch tip. The next fatigue crack growth occurred in a vertical direction towards the direction of cyclic loading. The fatigue crack growth was little bit different in the single step heat treatment. In the initial part, the crack tended to be in straight direction and in the following part; it slightly experienced a change in direction. This phenomenon indicates that the fatigue crack growth experienced by single step tended to have a delay. In this case, the very different performance of the fatigue crack growth is highly determined by nodular distribution, distance between nodules, the size of nodules and the phase of ferrite and pearlite matrix [9].

The fatigue crack path changed the behaviour controlled by the presence of nodular graphite. The crack growth always occurred in the interface of matrix graphite, while the nodular graphite was still not broken. This is the characteristic for both two single step treatments. The crack of nodular graphite spread mainly through pearlite, which, due to its refined flat composite, provided an advantageous condition for the crack growth.

As reported previously, the matrix of the result of heat treatment consisted of ferrite and pearlite. The crack always started in the graphite matrix and spread along the energy course commonly as an interface between laths ferrite and pearlite. According to [10] the interface 
matrix graphite is relatively irregular with a sharp angle that, in some cases, is the microcracks coming from the nodule. The main fore space enhances the value of the stress intensity factor in the spot of crack initiation. This then stimulates the growth of microcracks from the nodules towards the main space to the opposite direction of the growth with the general crack growth until it joins with the main crack. In this case, the common crack path continuously occurs in some other spots in all nodules in which the advantageous condition lies in the beginning of a new space that makes a process of growth, and repeats the process when facing other nodules. This mechanism then justifies the existence of crack branching as observed from the concurrence between the main crack and the nodular.

The secondary initiation of microcracks was observed near the main crack. When the small cracks simultaneously spread except the main cracks, the existing elastic energy for the growth from the main cracks certainly would be reduced, particularly in view of the creation of the larger crack surface; thus reducing the general level of crack growth. In some cases, it locally can cause a sudden crack. In addition, the orientation of the ferrite laths in matrix can influence the crack path. The space frequently spreads along the ferrite-austenite interface located more or less normal towards the applied load direction in which the small cracks cut through the bainite ferrite laths located in parallel towards the applied loading direction. On the other side, as some bainite ferrite laths commonly have the equal orientation, laths cluster is shaped then. In general, the orientation of each single group, however, is various.

Theoretically, the transformation of the temperature above $350^{\circ} \mathrm{C}$ can result in the coarser ausferrite matrix called upper ausferrite showing an acicular structure. Meanwhile, in the transformation of the lower temperature under $350^{\circ} \mathrm{C}$, the more refined ausferrite matrix could be obtained called bottom ausferrite presenting a structure that highly resembled to the martensitic temper. For the austempered time of 60 minutes in the two-step austempered the highest toughness occurred at the temperature of $340^{\circ} \mathrm{C}$. For the austempered time of 120 minutes, the highest toughness occurred at the temperature of $340^{\circ} \mathrm{C}$ and the lowest one was at the temperature of $280^{\circ} \mathrm{C}$. This was in view of the formation of bottom ausferrite with few of the remaining austenite with higher percentage of acicular ferrite phase compared to the remaining austenite. At the temperature of $280^{\circ} \mathrm{C}$ the matrix structure formed was upper ausferrite (coarse ausferrite) resembling to the refined pearlite [9].

\section{Summary}

Based on the research results, it is observed that the single step heat treatment at the austempered temperature at $340^{\circ} \mathrm{C}$ with the holding time of 120 minutes showed a slower fatigue crack growth rate in comparison to the single step heat treatment at the temperature of 310 , and $280^{\circ} \mathrm{C}$ with the holding time of 60 minutes. The slowness of the fatigue crack growth rate particularly is indicated by the higher percentage of pearlite matrix phase in comparison to the ferrite matrix, nodular distance, nodular size and the relatively even nodular distribution.

I would like to express my gratitude to Engineering Faculty, Universitas Negeri Malang which fully supports the opportunity to join AGS 2016 Conference

\section{References}

1. W. Siefer, K. Orths, T. Am. Fish. Soc., 78, 382 (1970)

2. Andoko, Rudy Soenoko, P. Anindito, Yudy S. Irawan, International Journal of Applied Engineering Research, 9(5), 541 (2014)

3. AFS 115th Metalcasting Congress, (Schaumburg, IL USA, 2011)

4. O. Eric, D. Rajnovic, S. Zec, L. Sidjani, T. Milan, Mater. Charact., 57, 211 (2006) 
5. J. Zimba, D.J. Simbi, E. Navara, Cem. Concr. Compos., 25, 643 (2003)

6. Andoko, P. Poppy, ARPN Journal of Engineering and Applied Sciences, 11(2), 863 (2016)

7. R.A. Gonzaga, P.M. Landa, A. Peres, P. Villanueva, Journal of Achievements in Materials and Manufacturing Engineering, 33(2), 150 (2009)

8. N. Costa, N. Machado, F.S. Silva, Ciencia \& Tecnologia dos Materiais, 20, 120 (2008)

9. Andoko, Rudy Sonoko, P. Anindito, Yudi S. Irawan, Aust. J. Basic Appl. Sci., 8(3), 277 (2014)

10. G.L. Greno, J.L. Otegui, R.E. Boeri, Int. J. Fatigue, 21, 35 (1999) 